\title{
Price Comparison and Analysis of Alternative Fuels for Indian Cement Industry
}

\author{
Aditya Thakur' ${ }^{1}$, Rahul Verma ${ }^{2}$ \\ ${ }^{1} \mathrm{PG}$ - Economics, Chandigarh University, Punjab \\ ${ }^{2} \mathrm{UG}$ - Mechanical Engineering, Vellore Institute of Technology, Vellore
}

\begin{abstract}
This paper involves selection of alternative fuels for Indian cement industries. Currently pet coke is the major fuel used to fire cement kilns. Its characteristic of being cheap and its appreciable combustion efficiency does not overlook the harmful emission produced during its combustion. In this paper, a case of UMA cement factory located in Udhampur, Jammu and Kashmir is considered. Survey conducted in this cement factory reported that a total of $120 \mathrm{~kg}$ of pet coke is used in order to produce one tonne of cement. On the basis of energy requirement for the combustion, four alternative fuels were selected meticulously. This study involves price analysis of each alternative fuel along with pet coke and is detailed analysis is provided tabularly. Moreover, $\mathrm{CO} 2$ emission of each fuel in producing one tonne of cement is also calculated in this paper and is provided graphically in this paper.
\end{abstract}

Keywords: Alternative Fuels, Industrial pollution and Cement Kiln

\section{INTRODUCTION}

Studies conducted in recent years have stated that economic indicators are one of the major tools used to take the followup of the progress. Due to this, India's major priority following independence was rapid industrialization in order to achieve economic prosperity. Development of an economy depends on its ability to grow the industrial sector [1]. Since the late 1980s, Indian firms and industries have grown tremendously, especially in the Urban areas. Continuous growth in industrial sector resulted into generating major environment issue which is uncontrolled pollution (CPCB, 2010) [2]. Long-term impacts of pollution not only have negative effects on human health, but also affects economic growth of a country. Over a 24-hour period in India, millions of people inhale up to 25 micrograms/cubic metre of the deadly microscopic pollutant PM2.5, which is far greater than WHO's standard of 10 micrograms/cubic metre [3]. Inhaling toxic air repeatedly may lead to cardiovascular and respiratory diseases, lung and other types of cancer, strokes, preterm birth, type-2 diabetes, and many other diseases [4][5]. As per the pollution report 2019, 21 Indian cities were reflected in top 30 polluted cities in the world. Air quality index of some highest polluting Indian cities is provided in table 1 [6]. Among all pollution sources, $51 \%$ pollution comes from industry, $27 \%$ is from Vehicles, $17 \%$ comes from crop burning, and 5\% is from other sources. India experiences approximately 2 million premature deaths by inhaling harmful gases emitted from the above-mentioned pollution sources.

Table 1. Air quality index of most polluted Indian cities [6]

\begin{tabular}{|l|l|}
\hline Cities & $\begin{array}{l}\text { PM2.5 } \\
\text { Levels }\end{array}$ \\
\hline Ghaziabad, Uttar Pradesh & 258 \\
\hline Sitapur, Uttar Pradesh & 254 \\
\hline Singrauli, Madhya Pradesh & 244 \\
\hline Loni, Uttar Pradesh & 236 \\
\hline Pitampura, Delhi & 229 \\
\hline Dasna, Uttar Pradesh & 226 \\
\hline Unnao, Uttar Pradesh & 223 \\
\hline Gwalior, Madhya Pradesh & 209 \\
\hline Patna, Bihar & 207 \\
\hline Nanpara, Uttar Pradesh & 197 \\
\hline Karol Bagh, Delhi & 194 \\
\hline
\end{tabular}

In 2019, India initiated the National Clean Air Programme (NCAP) which aims in reducing PM2.5 and PM10 concentration levels by $20-30 \%$ by the end of 2024. Similarly, other countries have also introduced several initiatives to control the air pollution. Chenet et al. 2019 [7] and whitley et al. 2018 [8] have reported that the finance sector is an important sector in dealing with the implementation of a Zero-carbon transition. According to the United Nations $2015 \mathrm{a}$ 


\section{International Advanced Research Journal in Science, Engineering and Technology \\ Impact Factor $7.105 \div$ Vol. 9, Issue 1, January 2022 \\ DOI: 10.17148/IARJSET.2022.9154}

[9] and UNFCCC 2018 [10], the Paris climate agreement and the 2030 Sustainable Development Agenda will require a total of US $\$ 100$ billion. Climate Policy Initiative 2018 [11] reported that limiting the rise in temperature to $1.5^{\circ} \mathrm{C}$ will require funding in the range of US\$ 2-3.6 trillion from 2020 to 2050 . While many countries are trying to provide solution for the reduction of industrial emissions, India have provided a proposal to diminish entire emission by 2070.

India is a country where coal is used as a major fuel for the production of energy. Coal is used in most of the industries to generate power as it is the cheapest source of energy. One such industry which uses coal as a fuel is cement industry [12]. Cement industry plays a vital role for the development of the country in terms of construction. After China, India manufactures highest amount of cement in the entire world. Cement is a basic yet important requirement of all construction activities as it is used in construction of housing, dams, bridges, industrial construction, roads and cement production process. India has approximately 210 large and 365 small cement plants. Data analysis have reported that the production of cement has been increased by $7.8 \%$ over a one-year time frame, from February 2020 to 2021 [13][14]. A total of 262 million tonnes (MT) of cement is produced in India for financial year 2021 (through February 2021). In financial year 2022, while cement production is expected to rise by $10 \%$ to $12 \%$, its utilization is expected to reach up to $65 \%$.

It is well known that India's Cement industry has earned a world reputation as begin the best in the world. But Cement industry is also recognized as one of the largest polluters of the environment, as it contributes around 7\% carbon emission globally and generates a large amount of particular matter (PM) emission [15]. This emission is caused by during the firing process which uses pet coke as a fuel in cement kiln. Cement industries are being pushed to reduce emission because these are one of the largest industrial sources of carbon dioxide emission $\left(\mathrm{CO}_{2}\right)$, Sulphur dioxide $\left(\mathrm{SO}_{2}\right)$, Nitrogen Dioxide $\left(\mathrm{NO}_{2}\right)$ and Particular Matter. In the process of moving towards eco-friendly production of cement, many cement plants have started to replace pet coke by alternative fuels [16]. These alternative fuels are tires and rubber waste, plastic waste, thermal fraction of domestic waste, sewage sludge, animal meal, municipal solid waste (MSW), etc [17]. Use of alternative fuels has both ecological and economic benefits in cement plants. This paper provides a detailed analysis of various alternative fuels which can replace pet coke as a fuel in cement kiln.

\section{LITERATURE BACKGROUND}

Importance and requirement of cement is linearly increasing with the increase in population. Therefore, to minimise the $\mathrm{CO} 2$ emission it is extremely necessary to provide alternative solutions for firing cement kiln which is currently fired using pet coke. This paper involves a case of UMA Cement factory which also uses pet coke as a fuel. As per survey conducted in UMA cement factory, it was found that approximately $120 \mathrm{~kg}$ of pet coke is used to produce one tonne of cement. It was also noticed that it was highly unlikely to fire $100 \%$ of the pet coke in the kiln due to non-availability of retrofitted precalciners. Thus, the left-over pet coke is likely to be reinforced with the clinkers which may further degrade the cement quality [18].

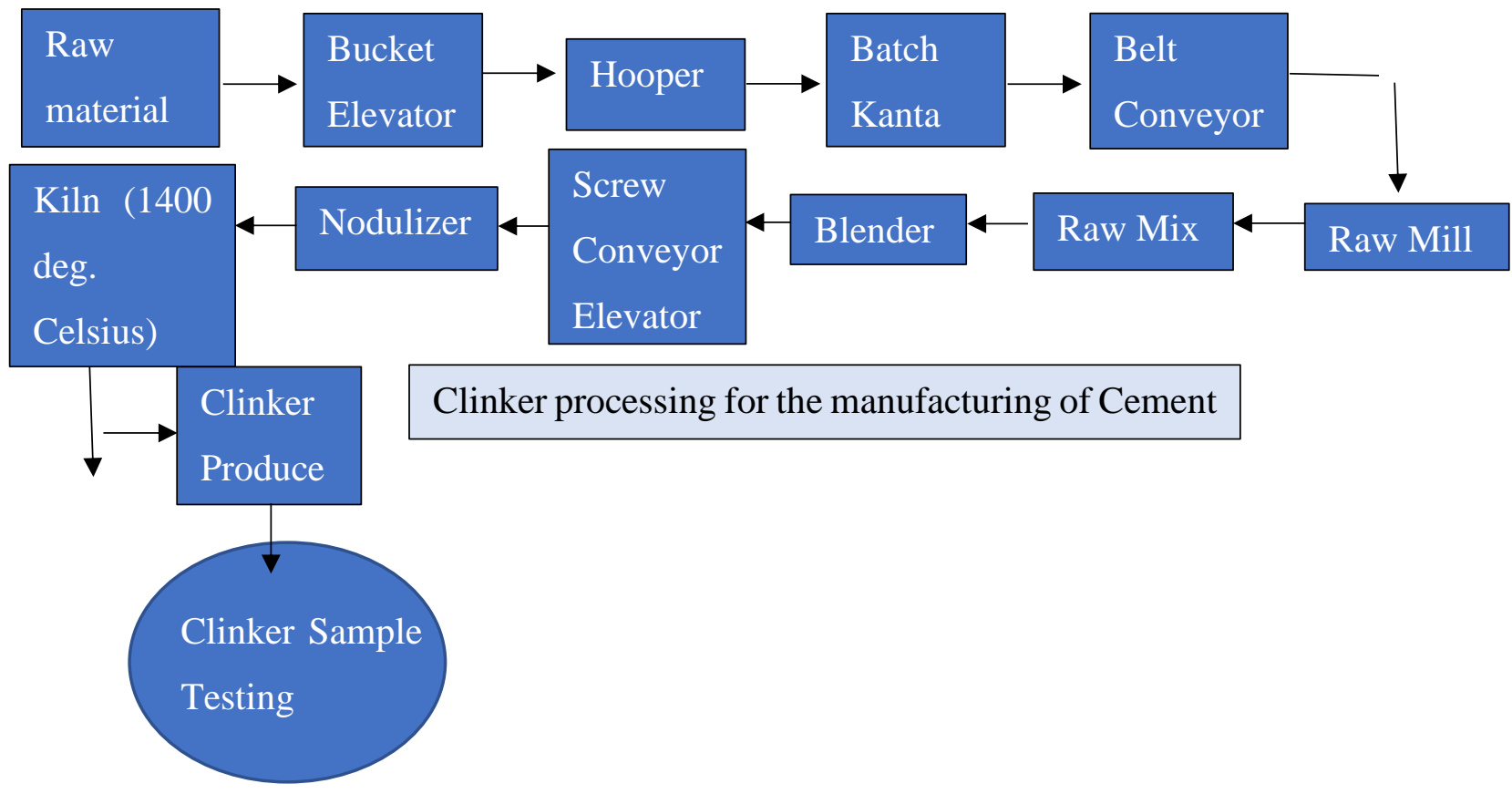

Fig 1. Flow chart for cement manufacturing in UMA Cement factory 


\section{International Advanced Research Journal in Science, Engineering and Technology \\ Impact Factor $7.105 \div$ Vol. 9, Issue 1, January 2022 \\ DOI: 10.17148/IARJSET.2022.9154}

Moreover, previous studies have also reported that people working in cement factories and residing in nearby places have weak lungs and are highly prone to lung cancer when compared to a normal human being. Considering these data and studies it is extremely necessary to introduce alternative fuels in cement factories. Figure 1 shows brief understanding cement manufacturing process in UMA cement factory planted in Udhampur, Jammu and Kashmir.

Reduction in requirement of waste disposal and conservation of non-renewable resources are the two major reasons for using alternative fuels in cement kilns. Cembureau in 1996 [19] performed in depth study on alternative fuels and reported that almost 2.5 million tonnes of coal are saved every year in European cement kilns by using alternative fuels for firing. Study conducted by Mokrzycki et al. in 2003 [16] reported the usage of alternative fuels in European cement kilns from the year 1990 to 1998. Usage of alternative fuels in these cement industries are provided in table 2.

Table 2. List of countries using alternative fuels in cement kilns

\begin{tabular}{|l|l|}
\hline COUNTRY & USAGE PERCENTAGE \\
\hline France & $52.4 \%$ \\
\hline Switzerland & $25 \%$ \\
\hline Great Britain & $20 \%$ \\
\hline Belgium & $18 \%$ \\
\hline Germany & $15 \%$ \\
\hline Italy & $4.1 \%$ \\
\hline
\end{tabular}

Characteristics of cement kiln such as high temperature $\left(1400^{\circ} \mathrm{C}\right)$, oxidising atmosphere, alkaline surroundings, long residence times and high thermal inertial creates optimum conditions in order to fuel cement kiln with alternative fuels instead of pet coke (Chinyama MP, 2009) [20]. These conditions are extremely favourable to ensure complete destruction of the organic part of the fuel and leave the inorganic part which may include heavy metals. This paper involves detailed price analysis of four alternative fuels and its comparison with the present fuel (pet coke). Calculation of $\mathrm{CO}_{2} \mathrm{emission}$ for each fuel considered in this study, is also performed using mathematical formula.

\section{RESULTS AND DISCUSSION}

Considering the harmful effects of pet coke, four alternative fuels: Producer gas, Natural gas, Biogas ( $60 \%$ methane and $\sim 40 \% \mathrm{CO}_{2}$ ) and Green Hydrogen are selected in this study to conduct a detailed price analysis and comparison. The selection process of alternative fuels is carried out meticulously considering various economic factors, environmental factors and calorific value of the fuel. Total energy required for the production of one tonne of cement along with fuel requirement is given in detail.

\subsection{Pet coke}

During the process of oil refining, pet coke is received as its by-product. Less specific energy cost of pet coke over coal and oil, is the main reason for its tremendous use in cement industries. Important characteristic of pet coke includes its high calorific value, low ash and low volatile matter [21]. Calculation showed that total energy required in cement kiln to produce one tonne of cement is $4.8 \times 10^{4} \mathrm{Kcal}$. Table 3 provides exact price of pet coke required for the manufacturing of one tonne of cement.

Table 3. Price analysis of pet coke

\begin{tabular}{|l|l|l|l|}
\hline $\begin{array}{l}\text { Calorific } \\
(\text { Kcal/kg) }\end{array}$ & Amount of Fuel required & Price of fuel per kg & $\begin{array}{l}\text { Total price (Excluding } \\
\text { storage and Handling } \\
\text { charges) }\end{array}$ \\
\hline 4000 & $120 \mathrm{~kg}$ & Rs. 30 & Rs. 3,600 \\
\hline
\end{tabular}

\subsection{Producer Gas}

Composition of producer gas consists of carbon monoxide, hydrogen and methane. One of the most economic methods to produce producer gas is pet coke gasification, which is a well-known thermo-chemical process. Studies have stated that producer gas can not only provide highly efficient combustion in cement kiln, but also generate much lower particulate matter when compared to pet coke. Moreover, an easy conversion of producer gas into chemicals such as dimethyl ether and methanol is also an area of interest as these chemicals produces almost negligible particulate matter [22]. Numerical analysis carried out on the basis of its calorific value and total energy requirement $\left(4.8 \times 10^{4} \mathrm{Kcal}\right)$ reported that a total of $400 \mathrm{~kg}$ of producer gas is required to produce one tonne of cement. Detailed price analysis of the same is provided in table 4. 


\section{International Advanced Research Journal in Science, Engineering and Technology \\ Impact Factor $7.105 \div$ Vol. 9, Issue 1, January 2022 \\ DOI: 10.17148/IARJSET.2022.9154}

Table 4. Price analysis of producer gas

\begin{tabular}{|l|l|l|l|}
\hline $\begin{array}{l}\text { Calorific Value } \\
\text { (Kcal/kg) }\end{array}$ & Amount of fuel required & Price of fuel per kg & $\begin{array}{l}\text { Total price (Excluding } \\
\text { storage and Handling } \\
\text { charges) }\end{array}$ \\
\hline 1200 & $400 \mathrm{~kg}$ & Rs. 15 & Rs. 6,000 \\
\hline
\end{tabular}

\subsection{Natural Gas}

Natural Gas is considered as a clean combustion gas as it produces much less harmful emissions when compared with pet coke. When methanogens undergo anaerobic decomposition inside the earth's crust, natural gas is produced. Moreover, natural gas can also be easily manufactured at large scale by chemical reactions of soda-lime and sodium ethanoate. Natural gas is extremely flammable due to the presence of high standard hydrocarbons [23]. During combustion, it produces carbon dioxide, water vapours and excessive heat. Previous researcher has stated that using natural gas as a firing fuel in cement kilns can increase clinker production by 5-10\%. Excellent ability of mixing of natural gas with air not only provides better combustion efficiency when compared to pet coke, but also reduces the air escaping kiln tower by approximately 8 percent [24]. It possesses high calorific value than pet coke which results into decrement in fuel requirement for the production of one tonne of cement. Calculations are performed on the basis of energy requirement and calorific value and it is observed that $40 \mathrm{~kg}$ natural gas is required to manufacture one tonne of cement. Table 5 shows price analysis of natural gas as per the requirement.

Table 5. Price analysis of natural gas

\begin{tabular}{|l|l|l|l|}
\hline $\begin{array}{l}\text { Calorific Value } \\
(\text { Kcal/kg) }\end{array}$ & Amount of fuel required & Price of fuel per kg & $\begin{array}{l}\text { Total price (Excluding } \\
\text { storage and Handling } \\
\text { charges) }\end{array}$ \\
\hline 12000 & $40 \mathrm{~kg}$ & Rs. 60 & Rs. 2,400 \\
\hline
\end{tabular}

\subsection{Biogas ( $\sim 60 \%$ methane and $\left.\sim 40 \% \mathrm{CO}_{2}\right)$}

Biogas is an extremely clean source of energy and is gaining popularity globally. The production process of biogas is easy as well as economic when compared to other fuels. Biogas is produced from anaerobic decomposition carried out in the non-presence of air [25]. It is obtained from natural organic materials such as animal waste, food waste and residues of crops. It possesses slightly higher calorific value than pet coke which implies that energy produced by the combustion of biogas will be higher than that of energy from pet coke [26]. Due to the presence of methane, biogas is extremely flammable and may provide higher combustion efficiency than pet coke. On performing meticulous numerical analysis, it was found that a total of $115 \mathrm{~kg}$ of bio gas is required to produce adequate energy in order to produce one tonne of cement. Detailed price analysis of biogas is given in table 6.

Table 6. Price analysis of biogas

\begin{tabular}{|l|l|l|l|}
\hline $\begin{array}{l}\text { Calorific Value } \\
(\mathrm{Kcal} / \mathrm{kg})\end{array}$ & Amount of fuel required & Price of fuel per kg & $\begin{array}{l}\text { Total price } \\
\text { (Excluding storage and } \\
\text { Handling charges) }\end{array}$ \\
\hline 4200 & $115 \mathrm{~kg}$ & Rs. 22 & Rs. 2,530 \\
\hline
\end{tabular}

\subsection{Green Hydrogen}

In February 2021, a popular cement company named CEMEX reported that they have successfully implemented hydrogen-based technology to fire cement kiln. Hydrogen is already been used as a fuel in automobiles and even in various space shuttles. Being highly flammable, having extremely high calorific value and its abundant presence in nature make hydrogen as a preferred fuel choice in upcoming times. Using hydrogen as a fuel in Indian cement industries will reduce the $\mathrm{CO}_{2}$ emission at much higher level as hydrogen does not emit any $\mathrm{CO}_{2}$ during the combustion [27][28]. Production of hydrogen can be easily carried out using the method of electrolysis. Various studies have reported that there will be immense drop in production price of hydrogen by 2030 which will ease the implementation of hydrogen-based technology in Indian cement sector. Calculations carried out on the basis of calorific value for the requirement of green hydrogen to produce one tonne of cement showed that approximately $16 \mathrm{~kg}$ of hydrogen is required. The price analysis of the same is given in table 7 .

Table 7. Price analysis of green hydrogen

\begin{tabular}{|l|l|l|l|}
\hline $\begin{array}{l}\text { Calorific } \\
(\text { Kcal/kg) }\end{array}$ & Amount of fuel required & Price of fuel per kg & $\begin{array}{l}\text { Total price } \\
\text { (Excluding storage and } \\
\text { Handling charges) }\end{array}$ \\
\hline 28600 & $16 \mathrm{~kg}$ & Rs. 300 & Rs. 4,800 \\
\hline
\end{tabular}




\section{International Advanced Research Journal in Science, Engineering and Technology \\ Impact Factor $7.105 \div$ Vol. 9, Issue 1, January 2022 \\ DOI: 10.17148/IARJSET.2022.9154}

Entire analysis showed that with minimal alternations in fuel investments, cement industries in India can move towards green production of cement. To provide transparent and lucid understanding of price analysis, change in percentage of fuel requirement and total price for each alternative fuel with respect to pet coke is provided in table $8 . \mathrm{Moreover}^{\mathrm{CO}} \mathrm{C}_{2}$ analysis for each fuel along with pet coke is also carried out in this research using equation 1 [29]. While $\mathrm{CO}_{2}$ emission analysis for each fuel showed that pet coke produces highest amount of carbon dioxide during the production of one tonne of cement, hydrogen has zero emission. $\mathrm{CO} 2$ emission for each fuel is graphically shown in figure 2.

$\mathrm{ECO}_{2}=\left(\frac{\mathrm{C}_{f}}{\mathrm{H}_{f}}\right) \times\left(\frac{\mathrm{McO}_{2}}{\mathrm{Mc}}\right)$--------- (1) [29]

Where: $\mathrm{E}_{\mathrm{CO} 2}=$ specific $\mathrm{CO} 2$ emission $[\mathrm{kgCO} 2 / \mathrm{kWh}]$

$\mathrm{C}_{\mathrm{f}}=$ specific carbon content in the fuel $[\mathrm{kgC} / \mathrm{kgfuel}]$

$\mathrm{H}_{\mathrm{f}}=$ specific energy content in the fuel [kWh/kgfuel]

$\mathbf{M}_{\mathrm{c}}=$ Molecular weight Carbon [ $\mathrm{kg} / \mathrm{kmol}$ Carbon]

$\mathrm{M}_{\mathrm{CO} 2}=$ Molecular weight Carbon Dioxide $[\mathrm{kg} / \mathrm{kmol} \mathrm{CO} 2]$

Table 8. Percentage change in price and fuel requirement

\begin{tabular}{|l|l|l|}
\hline Fuel & $\begin{array}{l}\text { Change in \% for fuel requirement } \\
\text { with respect to pet coke }\end{array}$ & $\begin{array}{l}\text { Change in \% for total price with } \\
\text { respect to pet coke }\end{array}$ \\
\hline Producer gas & $333 \%$ increase & $60 \%$ increase \\
\hline Natural gas & $66.7 \%$ decrease & $33.3 \%$ decrease \\
\hline Biogas & $4.16 \%$ decrease & $29.7 \%$ decrease \\
\hline Hydrogen & $86.66 \%$ decrease & $25 \%$ increase \\
\hline
\end{tabular}

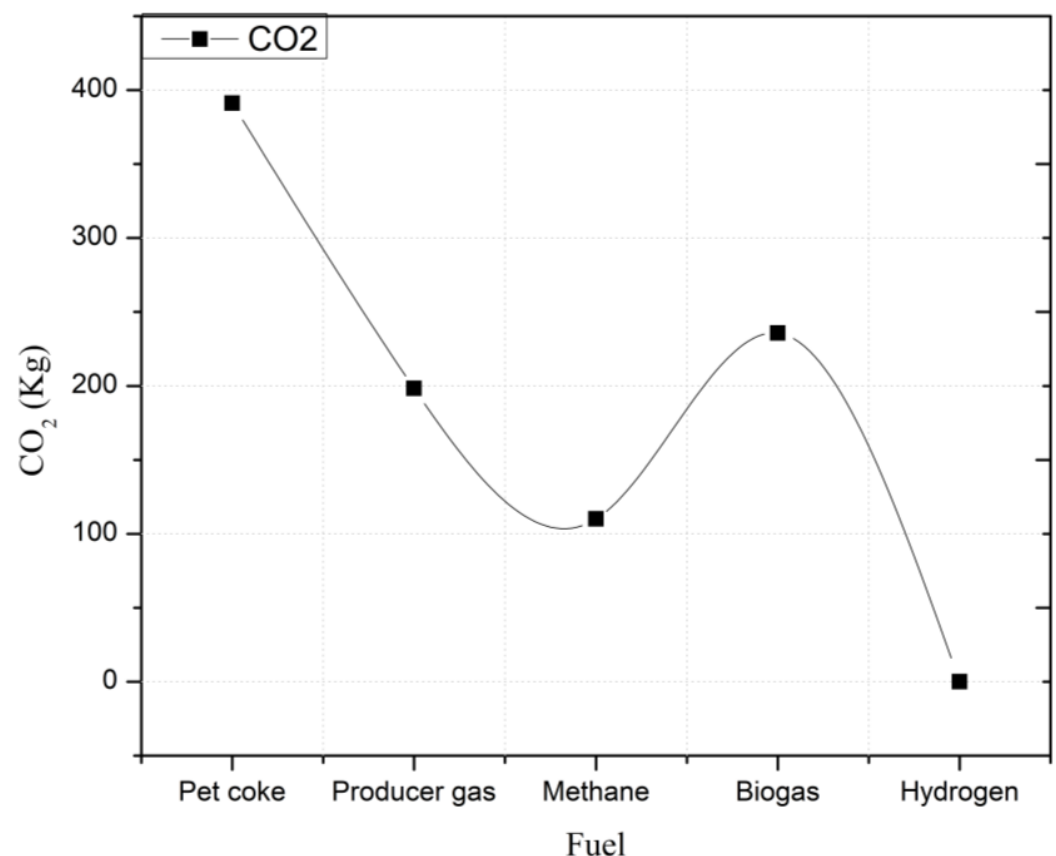

Fig. 2. Change in $\mathrm{CO}_{2}$ emission

Therefore, use of natural gas in cement industries can be result into best results in terms of $\mathrm{CO}_{2}$ emissions and Economics. Moreover, hydrogen-based technology is the future of cement industries in India as it is the cleanest source of energy and possesses great combustion efficiency when compared to any other fuel.

\section{CONCLUSION}

On performing various mathematical calculations and literature study, four alternative fuels named producer gas, natural gas, biogas and green hydrogen is selected to replace pet coke as a fuel in UMA cement factory as well as in Indian cement industries. These alternative fuels were selected based on per $\mathrm{kg}$ price, calorific value and emissions during burning. It was found that only $40 \mathrm{~kg}$ of natural gas is required to produce one tonne of cement which costs Rs. 2400 whereas this value is $120 \mathrm{~kg}$ for pet coke which costs Rs. 3600. Similarly, price analysis is carried out for each alternative 


\section{International Advanced Research Journal in Science, Engineering and Technology \\ Impact Factor $7.105 \div$ Vol. 9, Issue 1, January 2022 \\ DOI: 10.17148/IARJSET.2022.9154}

fuel along with pet coke. Moreover, $\mathrm{CO} 2$ emissions for pet coke and other selected fuels is also calculated in this paper and it was observed that pet coke has highest $\mathrm{CO} 2$ emission followed by biogas, producer gas, natural gas and hydrogen (Zero emission). Entire data analysis and comparison is provided in tabular form and graphically for clear understanding of each aspect.

\section{REFERENCES}

1. Khan M, Tarique M. Industrial Pollution in Indian Industries: A Post Reform Scenario. Journal of Energy Research and Environmental Technology. 2015;2:182-7.

2. Shrivastava M, Ghosh A, Bhattacharyya R, Singh SD. Urban pollution in India. John Wiley \& Sons, Ltd.: Chichester, UK. 2018 Oct 9:341-56.

3. Balakrishnan K, Dey S, Gupta T, Dhaliwal RS, Brauer M, Cohen AJ, Stanaway JD, Beig G, Joshi TK, Aggarwal AN, Sabde Y. The impact of air pollution on deaths, disease burden, and life expectancy across the states of India: the Global Burden of Disease Study 2017. The Lancet Planetary Health. 2019 Jan 1;3(1):e26-39.

4. Sagar A, Balakrishnan K, Guttikunda S, Roychowdhury A, Smith KR. India leads the way: A health-centered strategy for air pollution. Environmental health perspectives. 2016 Jul;124(7):A116-7.

5. Pandey A, Brauer M, Cropper ML, Balakrishnan K, Mathur P, Dey S, Turkgulu B, Kumar GA, Khare M, Beig G, Gupta T. Health and economic impact of air pollution in the states of India: the Global Burden of Disease Study 2019. The Lancet Planetary Health. 2021 Jan 1;5(1):e25-38.

6. Iqair.com/Air-Quality-Index/India/top-10-cities/

7. Chenet, H., L. Zamarioli, B. Kretschmer, and R. Narvaez. 2019. From Transformational Climate Finance to Transforming the Financial System for Climate. RIPPLES COP21 Horizon 2020 Project.https://www.cop21ripples.eu/wp-content/uploads/2019/09/20190830_COP21- RIPPLES_D43a_Transforming-the-Financial-System.pdf.

8. Whitley, S., J. Thwaites, H. Wright, and C. Ott. 2018. Making Finance Consistent with Climate Goals — Insights for Operationalising Article 2.1c of the UNFCCC Paris Agreement. London: Overseas Development Institute. https://www.odi.org/sites/odi.org.uk/files/resource-documents/12557. pdf.

9. United Nations. 2015a. The 2030 Agenda for Sustainable Development. New York, USA. https:// sustainabledevelopment.un.org/content/documents/21252030 Agenda for Sustainable Development web.pdf.

10. UNFCCC. 2018. UNFCCC Standing Committee on Finance: 2018 Biennial Assessment and Overview of Climate Finance Flows: Technical Report. Geneva. https://unfccc.int/sites/default/ files/resource/2018 BA Technical Report Final Feb 2019.pdf.

11. ÓhAiseadha C, Quinn G, Connolly R, Connolly M, Soon W. Energy and climate policy-An evaluation of global climate change expenditure 2011-2018. Energies. 2020 Jan;13(18):4839.

12. Madlool NA, Saidur R, Hossain MS, Rahim NA. A critical review on energy use and savings in the cement industries. Renewable and sustainable energy reviews. 2011 May 1;15(4):2042-60.

13. Priyadarshana $T$, Dissanayake R. Importance of consistent cement quality for a sustainable construction.

14. Pearson JC. Shrinkage of Portland Cement Mortars and Its Importance in Stucco Construction. InJournal Proceedings 1921 Feb 1 (Vol. 17, No. 2, pp. 133-148).

15. Shen L, Gao T, Zhao J, Wang L, Wang L, Liu L, Chen F, Xue J. Factory-level measurements on CO2 emission factors of cement production in China. Renewable and Sustainable Energy Reviews. 2014 Jun 1;34:337-49.

16. Mokrzycki E, Uliasz-Bocheńczyk A. Alternative fuels for the cement industry. Applied Energy. 2003 Jan 1;74(12):95-100.

17. Kaddatz KT, Rasul MG, Rahman A. Alternative fuels for use in cement kilns: process impact modelling. Procedia Engineering. 2013 Jan 1;56:413-20.

18. Chinyama MP. Alternative fuels in cement manufacturing. Alternative fuel. 2011 Aug 9:263-84.

19. CEMBUREAU. (1999), Environmental Benefits of Using Alternative Fuels in Cement Production. Brussels, The European Cement Association: 25.

20. Chinyama MP. Alternative fuels in cement manufacturing. Alternative fuel. 2011 Aug 9:263-84.

21. Yiqun L. Application of petroleum coke in cement industry and prospect analysis. petroleum processing and petrochemicals. 2020 oct 12;51(10):1.

22. Chanphavong L, Zainal ZA. Characterization and challenge of development of producer gas fuel combustor: A review. Journal of the Energy Institute. 2019 Oct 1;92(5):1577-90.

23. Jun D, Iida N. A study of high combustion efficiency and low CO emission in a natural gas HCCI engine. SAE transactions. 2004 Jan 1:1306-16.

24. Pohl JH, Tichenor BA, Lee J, Payne R. Combustion efficiency of flares. Combustion Science and Technology. 1986 Dec 1;50(4-6):217-31. 
25. Segundo-Aguilar A, González-Gutiérrez LV, Payá VC, Feliu J, Buitrón G, Cercado B. Energy and economic advantages of simultaneous hydrogen and biogas production in microbial electrolysis cells as a function of the applied voltage and biomass content. Sustainable Energy \& Fuels. 2021;5(7):2003-17.

26. Bagher AM, Fatemeh G, Saman M, Leili MM. Advantages and disadvantages of biogas energy. Bulletin of Advanced Scientific Research. 2015;1(5):132-5.

27. El-Emam RS, Gabriel KS. Synergizing hydrogen and cement industries for Canada's climate plan-case study. Energy Sources, Part A: Recovery, Utilization, and Environmental Effects. 2021 Dec 2;43(23):3151-65.

28. https://fuelcellsworks.com/news/cemex-successfully-deploys-hydrogen-based-ground-breaking-technology/

29. Engineering ToolBox, (2009). Combustion of Fuels - Carbon Dioxide Emission. [online] Available at: https://www.engineeringtoolbox.com/co2-emission-fuels-d_1085.html 